\title{
Distribusi Terduga Dan Kasus Baru di Sekitar Tempat Tinggal Penderita Tuberculosis Paru BTA Positif
}

\author{
Rana Hamidah $^{1}$, Wulandari Meikawati ${ }^{1 \oplus}$, Tri Dewi Kristini ${ }^{1,2}$ \\ ${ }^{1}$ Fakultas Kesehatan Masyarakat Universitas Muhammadiyah Semarang \\ ${ }^{2}$ Dinas Kesehatan Provinsi Jawa Tengah
}

\section{Info Artikel}

Diterima 20 Juni 2020

Disetujui 29 Juli 2020

Diterbitkan 30 November 2020

\section{Kata Kunci: \\ Kontak erat, M. Tuberculosis, \\ Terduga tuberculosis paru, \\ Tuberculosis paru. \\ e-ISSN: \\ 2613-9219 \\ Akreditasi Nasional: \\ Sinta 4 \\ ${ }^{\square}$ Coresponding author: wulandari@unimus.ac.id}

\author{
Keywords: \\ Close contact, \\ M. tuberculosis, \\ Pulmonary tuberculosis, \\ Suspected pulmonary \\ tuberculosis.
}

\begin{abstract}
Abstrak
Latar Belakang: Tuberculosis paru merupakan penyakit menular yang disebabkan $M$. Tuberculosis. Penularan terjadi ketika penderita TBC paru BTA positif batuk atau bersin dan tanpa disengaja penderita menyebarkan kuman ke udara dalam bentuk percikan dahak. Seorang penderita tuberculosis paru BTA positif dapat menginfeksi 10-15 orang di sekitarnya. penelitian ini bertujuan untuk mengetahui distribusi terduga dan kasus baru TBC paru di sekitar tempat tinggal penderita TBC paru BTA positif. Metode: Jenis penelitian analitik dengan rancangan cross sectional. Populasi dalam penelitian adalah 35 penderita TBC paru BTA positif yang didiagnosa pada bulan Januari-Maret 2019 dan sedang menjalani pengobatan di wilayah kerja puskesmas Tlogosari Wetan. Sampel dalam penelitian sebanyak 200 orang keluarga dan tetangga yang memiliki hubungan kontak erat dengan penderita TBC paru. Hasil: Rata- rata intensitas kontak responden sebesar 4,01 jam/hari, rata-rata kepadatan hunian responden $18,609 \mathrm{~m}^{2} /$ orang, responden yang merokok rata-rata sebesar 0,77 batang/hari, ventilasi kamar responden memiliki rata-rata sebesar $13,943 \%$ dan rata-rata status gizi responden yang sudah dewasa sebesar $22,875 \mathrm{~kg} / \mathrm{m}^{2}$ dan anak-anak $0,977 \mathrm{~kg} / \mathrm{m}^{2}$. Simpulan: Dari 200 responden yang terdiri dari 70 anggota keluarga dan 130 tetangga penderita TBC paru BTA positif ditemukan 5 orang terduga TBC paru yang $100 \%$ merupakan anggota keluarga penderita. Diantara 5 orang terduga TBC paru tidak didapatkan kasus baru TBC paru. Ada hubungan antara intensitas kontak dengan keberadaan terduga TBC paru dan tidak ada hubungan antara kepadatan hunian, kebiasaan merokok, ventilasi kamar dan status gizi dengan keberadaan terduga TBC paru.
\end{abstract}

\begin{abstract}
Background: Pulmonary tuberculosis is an infectious disease caused by M. tuberculosis. Transmission occurs when a positive smear pulmonary TB patient coughs or sneezes and the patient accidentally spreads germs into the air in the form of sputum sparks. A patient with positive smear pulmonary tuberculosis can infect $10-15$ people around him. This study aims to determine the distribution of suspected and new cases of pulmonary TB around the residence of patients with positive smear pulmonary TB. Method: The type of this research is analytic with a cross-sectional design. The population in this study were 35 positive smear pulmonary TB patients who were diagnosed in January-March 2019 and currently undergoing treatment in the work area of the Puskesmas Tlogosari Wetan. Sample this research is 200 families and neighbors who have close contact with pulmonary TB patients. Results: The average contact intensity of respondents was 4.01 hours/day, the average residential density of respondents was $18,609 \mathrm{~m} 2$ / person, respondents smoked an average of 0.76 cigarettes/day, the ventilation of respondents' rooms had an average of $13,943 \%$ and the average nutritional status of adult respondents was $22.875 \mathrm{~kg} / \mathrm{m} 2$ and children $0.977 \mathrm{~kg} / \mathrm{m} 2$. Conclusion: 200 respondents consisted of 70 family members and 130 neighbors patients positive smear pulmonary tuberculosis, 5 people suspected of having pulmonary tuberculosis were found to be $100 \%$, family members. The 5 people suspected of pulmonary TB isn't found new cases of pulmonary TB. There is a relationship between contact intensity with the presence of suspected pulmonary TB and there is no relationship between occupancy density, smoking habits, ventilation of rooms, and nutritional status with the presence of suspected pulmonary TB.
\end{abstract}




\section{Pendahuluan}

Tuberculosis paru yang sering dikenal dengan TBC paru adalah penyakit yang disebabkan bakteri $M$. Tuberculosis dan termasuk penyakit menular [1]. TBC paru mudah menginfeksi pengidap HIV AIDS [2], orang dengan status gizi buruk dan dipengaruhi oleh daya tahan tubuh seseorang [3]. Penularan TBC paru terjadi ketika percikan dahak penderita berada di udara dan terdapat sekitar 3000 percikan dahak yang dihasilkan [4]. Kuman TBC paru menyebar kepada orang lain melalui transmisi atau aliran udara (droplet dahak pasien TBC paru BTA positif) ketika penderita batuk atau bersin [3], [4].

TBC paru masih menjadi masalah kesehatan global [5]. WHO pada tahun 2017 melaporkan terdapat 1,3 juta kematian yang diakibatkan TBC paru dan terdapat 300.000 kematian diakibatkan TBC paru dengan HIV [6]. Indonesia merupakan negara dengan peringkat ketiga setelah India dan Cina dalam kasus TBC paru, ditunjukkan dari dua per tiga jumlah kasus TBC di dunia diduduki delapan negara, diantaranya India 27\%, Cina 9\%, Indonesia 8\%, Filipina 6\%, Pakistan 5\%, Nigeria dan Bangladesh masing-masing 4\% dan Afrika Selatan 3\% [6]. Prevalensi TBC paru di Indonesia terbagi menjadi tiga wilayah, diantaranya Sumatera 33\%, Jawa dan Bali 23\%, dan Indonesia bagian timur $44 \%$ [7].

Faktor risiko terduga TBC paru diantaranya adalah orang yang menetap satu atap rumah dengan penderita TBC paru BTA positif [4], tingkat pendidikan [8], kebiasaan merokok [7], [8] kondisi lingkungan fisik rumah [8], daya tahan tubuh, perilaku penderita TBC paru BTA positif yaitu kebiasaan membuang dahak sembarangan dan tidak menutup mulut ketika batuk atau bersin, serta kepadatan hunian yaitu perbandingan antara luas rumah dengan jumlah anggota keluarga [9]. Lamanya waktu kontak atau intensitas kontak dengan penderita TBC paru juga dapat menyebabkan seseorang terpapar M. tuberculosis [4].

Keberadaan kasus baru TBC paru merupakan salah satu masalah penting dalam upaya penanggulangan TBC paru [1]. Pengobatan pada penderita TBC paru BTA positif merupakan usaha untuk mengurangi angka kesakitan dan kematian akibat TBC dan sebagai kegiatan pencegahan penularan TBC paru yang ada di masyarakat [3]. Disamping itu juga dapat mengendalikan penularan $M$. Tuberculosis melalui deteksi kasus dan pengobatan pasien TBC paru [10], sehingga dapat memutus rantai infeksi. Penularan $M$. tuberculosis harus dihentikan untuk mencegah adanya terduga TBC dan kasus baru TBC [11].
Penemuan kasus TBC paru secara aktif lebih efektif dilakukan pada populasi berisiko tinggi, seperti yang dilakukan di Kamboja dengan melihat penderita TBC paru yang kontak serumah dan kontak tetangga [12]. Akan tetapi dengan adanya kasus TBC paru yang tinggi, penemuan kasus aktif sering tidak dilaksanakan dan mengakibatkan penundaan lama dalam diagnosis dan pengobatan [11].

Angka penemuan semua kasus TBC (Case Detection Rate) di Kota Semarang sejak bulan Januari hingga Desember tahun 2018 sebanyak 4.252 kasus. Puskesmas Tlogosari Wetan menduduki peringkat pertama sebagai fasilitas pelayanan kesehatan (Puskesmas) dengan angka temuan kasus TBC paru BTA positif tertinggi, yaitu sebanyak 66 kasus. Satu orang penderita tuberculosis paru BTA positif dapat menginfeksi 10-15 orang di sekitarnya selama 1 tahun, terutama pada orang yang sering berinteraksi atau kontak langsung [6]. Karena itu peneliti tertarik melakukan penelitian di Puskesmas Tlogosari Wetan Kota Semarang guna menghindari penularan tuberculosis yang cepat dan mengetahui distribusi terduga dan kasus baru TBC paru yang belum terlaporkan.

\section{Metode}

Jenis penelitian ini adalah analitik dengan menggunakan metode survai dan pemeriksaan dahak. Pendekatan yang digunakan adalah cross-sectional. Populasi dalam penelitian ini adalah seluruh penderita TBC paru BTA positif di wilayah kerja Puskesmas Tlogosari Wetan yang didiagnosa pada bulan Januari Maret 2019 yang berjumlah 35 orang, dan diperoleh sampel berdasarkan perhitungan menggunakan rumus slovin sebanyak 20 orang. Jumlah responden tiap sampel minimal 10 orang terdiri dari anggota keluarga dan tetangga yang memiliki hubungan kontak erat dengan penderita TBC paru BTA positif sehingga jumlah responden sebanyak 200 orang. Data yang diambil yaitu intensitas kontak, kepadatan hunian, kebiasaan merokok, ventilasi kamar dan status gizi serta dianalisis menggunakan uji Chi-square.

\section{Hasil}

Sebanyak 70 dari 200 responden (35\%) berasal dari anggota keluarga penderita yang terdiri dari 37 lakilaki dan 33 perempuan dan sebagian besar (65\%) merupakan tetangga penderita yang terdiri dari 63 lakilaki dan 67 perempuan. Usia responden berkisar antara 1-85 tahun. Usia responden yang berasal dari anggota keluarga penderita terbanyak terdapat pada kelompok usia anak-anak sebanyak 16 orang (23\%), sedangkan kelompok usia pada tetangga penderita yang terbanyak 
pada kategori usia lansia sebanyak 49 orang (38\%) (Gambar 1)

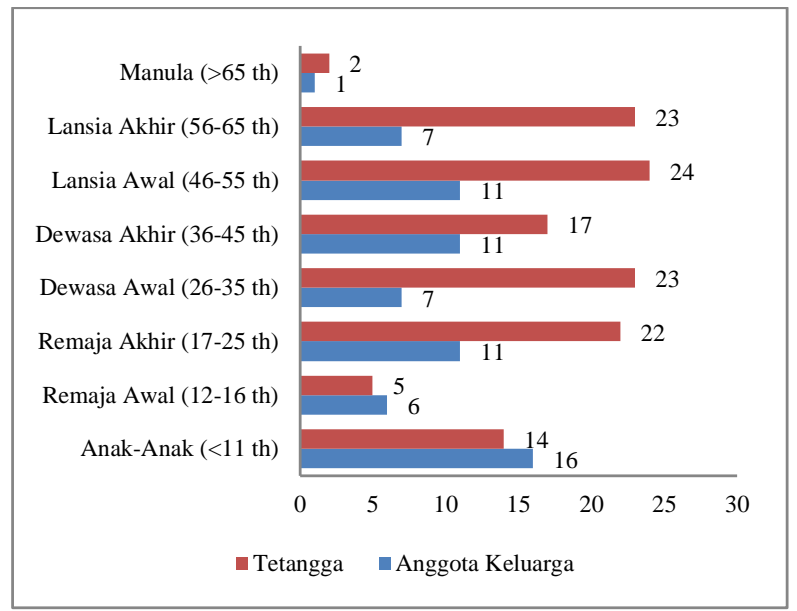

Gambar 1. Distribusi kategori usia responden

Populasi berisiko tertular TBC paru adalah kelompok usia anak-anak dan usia produktif (antara 1564 tahun) [13], responden pada penelitian ini yang berusia produktif sebanyak 159 orang (79,5\%). Penelitian diawali dengan melakukan skrining gejala klinis TBC paru kepada seluruh responden (anggota keluarga dan tetangga penderita). (Tabel 1)

Tabel 1. Distribusi Frekuensi Berdasarkan Gejala Klinis Tuberculosis Paru

\begin{tabular}{|c|c|c|c|c|c|c|c|c|}
\hline \multirow{3}{*}{$\begin{array}{c}\text { Gejala Klinis } \\
\text { TBC Paru }\end{array}$} & \multicolumn{4}{|c|}{ Ada } & \multicolumn{4}{|c|}{ Tidak Ada } \\
\hline & \multicolumn{2}{|c|}{$\begin{array}{l}\text { Anggota } \\
\text { Keluarga }\end{array}$} & \multicolumn{2}{|c|}{ Tetangga } & \multicolumn{2}{|c|}{$\begin{array}{l}\text { Anggota } \\
\text { Keluarga }\end{array}$} & \multicolumn{2}{|c|}{ Tetangga } \\
\hline & $\mathrm{f}$ & $\%$ & $\mathrm{f}$ & $\%$ & $\mathrm{f}$ & $\%$ & $\mathrm{f}$ & $\%$ \\
\hline $\begin{array}{l}\text { Batuk lama, } \\
\text { berdahak } 2 \\
\text { minggu/lebih }\end{array}$ & 5 & 7,1 & 0 & 0 & 65 & 92,9 & 130 & 100 \\
\hline $\begin{array}{l}\text { Batuk } \\
\text { bercampur } \\
\text { darah }\end{array}$ & 0 & 0 & 0 & 0 & 70 & 100 & 130 & 100 \\
\hline Sesak nafas & 0 & 0 & 0 & 0 & 70 & 100 & 130 & 100 \\
\hline Nyeri dada & 0 & 0 & 1 & 0,8 & 70 & 100 & 129 & 99,2 \\
\hline $\begin{array}{l}\text { Nafsu makan } \\
\text { menurun }\end{array}$ & 1 & 1,4 & 0 & 0 & 69 & 98,6 & 130 & 100 \\
\hline $\begin{array}{l}\text { Berat Badan } \\
\text { turun }\end{array}$ & 1 & 1,4 & 3 & 2,3 & 69 & 98,6 & 127 & 97,7 \\
\hline $\begin{array}{l}\text { Badan terasa } \\
\text { lemas }\end{array}$ & 1 & 1,4 & 0 & 0 & 69 & 98,6 & 130 & 100 \\
\hline $\begin{array}{l}\text { Demam/ } \\
\text { meriang } \\
\text { berkepanjangan }\end{array}$ & 0 & 0 & 0 & 0 & 70 & 100 & 130 & 100 \\
\hline $\begin{array}{l}\text { Berkeringat } \\
\text { malam hari } \\
\text { tanpa aktivitas }\end{array}$ & 0 & 0 & 0 & 0 & 70 & 100 & 130 & 100 \\
\hline
\end{tabular}

Responden yang memiliki gejala klinis TBC paru seperti batuk lama dan berdahak selama 2 minggu atau lebih ditemukan pada anggota keluarga penderita TBC paru BTA positif dan tidak ditemukan pada tetangga penderita. Dari 200 responden ditemukan sebanyak 5 orang terduga TBC paru dan seluruhnya merupakan anggota keluarga penderita TBC paru BTA positif. Lima orang terduga TBC paru yang ditemukan dalam penelitian ini berusia anak-anak, usia produktif dan lanjut usia. Karakteristik pasangan antara penderita TBC paru BTA positif dengan terduga TBC paru yang ditemukan. (Tabel 2)

Tabel 2. Pasangan Antara Penderita TBC Paru dengan Terduga TBC

\begin{tabular}{llll}
\hline \multicolumn{2}{c}{ Penderita TBC Paru } & \multicolumn{2}{c}{ Terduga TBC } \\
\hline Ibu & $(24$ th $)$ & Anak wanita & (2th) \\
Menantu pria & $(40$ th $)$ & Mertua pria & (63th) \\
Anak pria & $(34$ th $)$ & Ayah kandung & (61th) \\
Suami & $(68$ th) & Istri & (60th) \\
Ibu & $(60 t h)$ & Anak wanita & (41th) \\
\hline
\end{tabular}

Seluruh terduga TBC paru tinggal satu rumah dan memiliki hubungan kekeluargaan dengan penderita TBC paru BTA positif. Guna memastikan apakah terduga adalah kasus baru TBC paru atau tidak maka dilakukan pemeriksaan tes cepat molekuler (TCM) pada 4 orang dewasa terduga TBC paru dan didapatkan hasil TCM terduga TBC paru negatif seluruhnya. Pada anak usia 2 tahun semua hasil negative.

Tabel 3. Distribusi Frekuensi Vaiabel Bebas yang Diukur Dalam Penelitian

\begin{tabular}{|c|c|c|c|c|c|}
\hline \multirow{2}{*}{$\begin{array}{l}\text { Variabel } \\
\text { Bebas }\end{array}$} & \multirow{2}{*}{ Kategori } & \multicolumn{2}{|c|}{$\begin{array}{l}\text { Anggota } \\
\text { Keluarga }\end{array}$} & \multicolumn{2}{|c|}{ Tetangga } \\
\hline & & f & $\%$ & $\mathrm{f}$ & $\%$ \\
\hline \multirow{2}{*}{$\begin{array}{l}\text { Intensitas } \\
\text { Kontak }\end{array}$} & Berisiko $(\geq 8 \mathrm{jam} / \mathrm{hr})$ & 50 & 71,4 & 0 & 0 \\
\hline & $\begin{array}{l}\text { Tidak Berisiko }(< \\
8 \mathrm{jam} / \mathrm{hr})\end{array}$ & 20 & 28,6 & 130 & 100 \\
\hline \multirow{2}{*}{$\begin{array}{l}\text { Kepadatan } \\
\text { Hunian }\end{array}$} & Padat $\left(<9 \mathrm{~m}^{2} /\right.$ org $)$ & 0 & 0 & 4 & 3,1 \\
\hline & $\begin{array}{l}\text { Tidak Padat } \\
\left(\geq 9 \mathrm{~m}^{2} / \text { org }\right)\end{array}$ & 70 & 100 & 126 & 96,9 \\
\hline \multirow{4}{*}{$\begin{array}{l}\text { Kebiasaan } \\
\text { Merokok }\end{array}$} & $\begin{array}{l}\text { Perokok Berat }(\geq 15 \\
\text { batang) }\end{array}$ & 0 & 0 & 1 & 0,8 \\
\hline & $\begin{array}{l}\text { Perokok Sedang ( } 5 \text { - } \\
14 \text { batang) }\end{array}$ & 7 & 10 & 9 & 6,9 \\
\hline & $\begin{array}{l}\text { Perokok Ringan (1- } \\
4 \text { batang) }\end{array}$ & 1 & 1,4 & 0 & 0 \\
\hline & Tidak Merokok & 62 & 88,6 & 120 & 92,3 \\
\hline \multirow{2}{*}{$\begin{array}{l}\text { Ventilasi } \\
\text { Kamar }\end{array}$} & $\begin{array}{l}\text { Memenuhi Syarat } \\
\text { Kesehatan }\end{array}$ & 68 & 97,1 & 122 & 93,8 \\
\hline & $\begin{array}{l}\text { Tidak Memenuhi } \\
\text { Syarat kesehatan }\end{array}$ & 2 & 2,9 & 8 & 6,2 \\
\hline \multirow{3}{*}{$\begin{array}{l}\text { Status } \\
\text { Gizi }\end{array}$} & Kurus (IMT <18,5) & 1 & 1,4 & 4 & 3,1 \\
\hline & $\begin{array}{l}\text { Normal (IMT 18,5- } \\
24,9 \text { ) }\end{array}$ & 60 & 85,7 & 107 & 82,3 \\
\hline & Gemuk (IMT $\geq 25$ ) & 9 & 12,9 & 19 & 14,6 \\
\hline
\end{tabular}

Intensitas kontak yang berisiko ( $\geq 8$ jam/hari) pada keluarga sebanyak 71,4\%, kepadatan hunian dengan kategori padat pada tetangga sebanyak $3,1 \%$, anggota 
keluarga yang tidak merokok sebanyak 88,6\% sedangkan tetangga yang tidak merokok sebanyak $92,3 \%$, ventilasi kamar yang memenuhi syarat kesehatan pada keluarga sebanyak $97,1 \%$ dan status gizi normal (IMT 18,5-24,9) pada anggota keluarga sebanyak $85,7 \%$ dan sebanyak $82,3 \%$ pada tetangga.

Tabel 4. Hubungan antara variabel bebas dengan terduga tuberculosis paru

\begin{tabular}{llc}
\hline \multicolumn{1}{c}{$\begin{array}{c}\text { Variabel } \\
\text { Bebas }\end{array}$} & \multicolumn{1}{c}{ Kategori } & \multicolumn{1}{c}{$p$} \\
\hline Intensitas & Berisiko $(\geq 8 \mathrm{jam} / \mathrm{hr})$ & 0,001 \\
Kontak & Tdk Berisiko $(<8 \mathrm{jam} / \mathrm{hr})$ & \\
Kepadatan & Padat $\left(<9 \mathrm{~m}^{2} / \mathrm{org}\right)$ & 1,000 \\
Hunian & Tdk Padat $\left(\geq 9 \mathrm{~m}^{2} / \mathrm{org}\right)$ & \\
Kebiasaan & Merokok & 0,379 \\
Merokok & Tdk Merokok \\
Ventilasi & MS Kesehatan \\
Kamar & Tdk MS kesehatan & 1,000 \\
Status Gizi & $\begin{array}{l}\text { Kurus } \\
\text { Normal \& Gemuk }\end{array}$ \\
\hline
\end{tabular}

Ada hubungan antara intensitas kontak dengan keberadaan terduga TBC paru di Puskesmas Tlogosari Wetan dengan hasil uji Fishers Exact diperoleh nilai p $0,001<\alpha=0,05$ dan tidak ada hubungan antara kepadatan hunian, kebiasaan merokok, ventilasi kamar dan status gizi dengan keberadaan terduga TBC paru di Puksesmas Tlogosari Wetan dengan hasil uji Fishers Exact diperoleh nilai p secara berurutan p 1,000 > $\alpha=0,05, \mathrm{p} 0,379>\alpha=0,05, \mathrm{p} 1,000>\alpha=0,05$ dan $\mathrm{p} 0,120$ $>\alpha=0,05$.

\section{Pembahasan}

Seluruh terduga TBC paru memiliki intensitas kontak dengan penderita TBC paru BTA positif setiap harinya lebih dari 8 jam. Hal ini karena terduga TBC paru melakukan kegiatan sehari-hari secara bersamasama dengan penderita TBC paru. Diantaranya ada terduga TBC paru yang masih berusia 2 tahun yang selalu tidur sekamar dengan penderita TBC paru. Ditemukan juga terduga TBC paru yang berusia dewasa akhir masih masak bersama penderita (ibunya) karena memiliki usaha catering. Pada terduga TBC paru yang menginjak usia lansia akhir masih tidur, makan dan ngobrol bersama suaminya sebagai penderita TBC paru BTA positif. Semakin sering kontak dengan penderita TBC paru BTA positif semakin besar peluang terpapar M. tuberculosis karena kuman TBC mudah menyebar melalui udara pada orang yang berada di sekitar penderita terutama pada anak-anak [14] dan kontak penderita BTA positif kemungkinan lebih efektif daripada kontak penderita BTA negative [15].

Lima terduga TBC paru tidak ada yang tinggal di keluarga yang memiliki kepadatan hunian dengan kategori padat, hal ini karena jumlah penghuni rumah atau anggota keluarga yang tinggal satu atap berkisar antara 2 orang hingga 6 orang dengan luas rumah yang berkecukupan sehingga kepadatan hunian lebih dari atau sama dengan $9 \mathrm{~m}^{2}$ /orang. Penularan TBC paru berhubungan dengan kondisi rumah dengan kategori padat dan terdapat penderita TBC paru BTA positif [4], karena sumber penularan $\mathrm{TBC}$ paru adalah penderita TBC paru BTA positif. Sehingga tidak semua rumah yang memiliki kategori padat hunian selalu berisiko terkena TBC paru apabila di dalam rumah tersebut tidak terdapat penderita TBC paru BTA positif. Kemungkinan juga terjadi penularan TBC paru pada keluarga yang tidak padat hunian ataupun padat hunian jika di dalam rumah tersebut terdapat penderita TBC paru BTA positif [16]-[17].

Hasil penelitian di lapangan menunjukkan bahwa 5 orang terduga TBC paru mayoritas $(80 \%)$ bukan perokok, hanya seorang diantaranya memiliki kebiasaan merokok dengan kategori perokok ringan. Hal ini mungkin tidak terjadinya penularan TBC paru karena responden yang terduga TBC paru merupakan perokok ringan. Kemungkinan yang lain juga terjadi karena infeksi TBC laten, yaitu tidurnya $M$. tuberculosis dalam tubuh manusia dan sewaktu-waktu mampu menjadi TBC aktif [18]. Maka diperlukan kewaspadaan dari responden yang terduga TBC paru.

Ventilasi responden yang jarang dibuka dan tertutup akan menyebabkan udara di dalam ruangan tidak dapat tertukar dan tidak ada cahaya matahari yang masuk, kuman $M$. tuberculosis tidak mampu bertahan lama jika terkena cahaya matahari langsung [19]. Seluruh terduga TBC paru memiliki ventilasi kamar yang memenuhi syarat kesehatan yaitu lubang ventilasi kamar lebih dari atau sama dengan $10 \%$ luas lantai. Akan tetapi, masih ditemukan kesadaran yang kurang dari responden dalam hal ventilasi yang jarang dibuka dan masih ada ventilasi yang selalu tertutup sehingga ventilasi tidak berfungsi dengan semestinya.

Status gizi merupakan faktor yang menentukan tuberculosis di Banyumas terutama pada anak-anak karena kerentanan sistem kekebalan tubuh mereka terhadap infeksi TBC paru. Peran orang tua sangat dibutuhkan untuk mempertahankan status gizi anakanak [20]. terdapat 4 orang terduga TBC paru yang memiliki status gizi normal dan 1 orang terduga TBC paru memiliki status gizi kurus. Terduga TBC paru dengan status gizi kurus dimungkinkan karena terduga 
TBC paru sudah memasuki fase lansia akhir dan tidak memiliki gigi yang sempurna sehingga terjadi ketidakseimbangan energi positif dan mengalami penurunan berat badan [21].

\section{Kesimpulan}

Masih ditemukan 5 orang terduga TBC paru yang $100 \%$ merupakan anggota keluarga penderita dan tinggal satu rumah dengan penderita. Faktor berhubungan dengan kejadian terduga TBC paru adalah intensitas kontak dengan penderita.

\section{Rekomendasi}

Penelitian ini hanya melakukan pengamatan gejala-gejala klinis tuberculosis paru, tidak meneliti keterpaparannya. Perlu diwaspadai adanya infeksi tuberculosis laten, yaitu terjadi keterpaparan tapi responden tidak menunjukkan manifestasi klinis.

\section{Daftar Pustaka}

[1] Vidyastari YS, Cahyo K, Riyanti E. Faktor-Faktor Yang Mempengaruhi Pencapaian Target Cdr (Case Detection Rate) Oleh Koordinator P2tb Dalam Penemuan Kasus di Puskesmas Kota Semarang. Kesehat Masy. 2019;7(1).

[2] Buku Saku Kader Program Penanggulangan Tb. Indonesia DJ. Pengendalian Penyakit dan Penyehatan Lingkungan Departemen Kesehatan Republik. 2009.

[3] Dinas Kesehatan Jawa Tengah. Profil Kesehatan Provinsi Jawa Tengah. Vol 3511351.; 2016.

[4] Kementerian Kesehatan RI. Ditjen Penyakit dan Penyehatan Lingkungan. Pedoman Nasional Pengendalian Tuberculosis. 2011.

[5] Guno TH, Putra BA, Kamelia T, Makmun D. Diagnostic and Therapeutic Approach in Intestinal Tuberculosis. 2016;17(2).

[6] World Helath Organization. Global Tuberculosis Report.; 2018.

[7] Sugiarti S, Ramadhian MR, Carolia N. Vitamin D sebagai Suplemen dalam Terapi Tuberculosis Paru. 2018;7(11):198-202.

[8] Nurjana MA. Faktor Risiko Terjadinya Tuberculosis Paru Usia Produktif (15-49 Tahun) Di Indonesia. Media Litbangkes. 2015;25(3):163-170.

[9] Wulandari AA, Nurjazuli, Adi MS. Faktor Risiko dan Potensi Penularan Tuberculosis Paru di Kabupaten Kendal, Jawa Tengah. 2015;14(1):7-13.
[10] Shalsabila M, Cahyo SK, Indraswari R. Beberapa Faktor yang Mempengaruhi Pencapaian Target CDR Oleh Kader TB 'Aisyiyah Dalam Penemuan Kasus TB di Kota Semarang. 2018;6(4).

[11] Yuen CM, Amanullah F, Dharmadhikari A, et al. Turning off the tap: Stopping Tuberculosis Transmission Through Active Case-Finding and Prompt Effective Treatment. Lancet. 2015;386(10010):2334-2343.

[12] Morishita F, Eang MT, Nishikiori N, Yadav R. Increased Case Notification Through Active Case Finding of Tuberculosis Among Household and Neighbourhood Contacts in Cambodia. 2016:1-15. doi:10.1371/journal.pone.0150405

[13] Hadifah Z, Manik UA, Zulhaida A, Wilya V. Gambaran Penderita Tuberculosis Paru di Tiga Puskesmas Wilayah Kerja Kabupaten Pidie Propinsi Aceh. 2017;4:31-44.

[14] Febrian MA. Faktor-Faktor yang Berhubungan dengan Kejadian TB Paru Anak di Wilayah Puskesmas Garuda Kota Bandung. 2015;III(2):6479.

[15] Melsew YA, Doan TN, Gambhir M, Cheng AC, Mcbryde E. Risk Factors for Infectiousness of Patients With Tuberculosis: a systematic review and meta- analysis. 2019;(January 2017).

[16] Dotulong JFJ, Sapulete MR, Kandou GD. Hubungan Faktor Risiko Umur, Jenis Kelamin dan Kepadatan Hunian dengan Kejadian Penyakit TB Paru di Desa Wori Kecamatan Wori. Kedokt Komunitas dan Trop. 2015;III(2):57-65.

[17] Menteri Kesehatan RI. Peraturan Menteri Kesehatan RI nomor 67 tahun 2016. 2017;(122).

[18] Reviono. Pedoman Tatalaksana Infeksi Tuberculosis Laten Dari PDPI. In: ; 2016.

[19] Patil BN, Taranath TC. Limonia acidissima L . Leaf Mediated Synthesis Of Zinc Oxide Nanoparticles: A Potent Tool Against M. Tuberculosis. Int J Mycobacteriology. 2016;5(2):197-204. doi:10.1016/j.ijmyco.2016.03.004

[20]Zuraida ZF, Pramatama S, Wijayanti M. Risk Factors Associated With Childhood Tuberculosis: A Case Control Study In Endemic Tuberculosis Area. 2018;5(11):4702-4706.

[21] Schwenk A, Hodgson L, Wright A, et al. Nutrient Partitioning During Treatment of Tuberculosis : Gain In Body Fat Mass But Not In Protein Mass. 2004;(5):1006-1012. 